\title{
PENYULUHAN DAN PELATIHAN MANAJEMEN KONFLIK PADA ANGGOTA WANITA KATOLIK REPUBLIK INDONESIA (WKRI) CABANG ROH KUDUS TOMOHON
}

\author{
Gilly Marlya Tiwow \\ Fakultas Ekonomi, Universitas Negeri Manado \\ Email: jonesjilly216@gmail.com
}

\begin{abstract}
WKRI is an NGO (non Goverment Organization) that consist of Catholic women at age 18 above. The Scope of this women based organization is national. They have common identity as Catholic believer. But they vary in many background sauch as education, race, social and economy. These caused the organization was fragile to some friction in their daily activities. Some conflicts spread fast between the member. Sometimes the source of the conflicts even are insignificant. Furthermore, lack of knowledge and management skill could drive into longer time of conflict resolution-some couldnt be fixed. In the implication less and less catholic women interested joining the organization. This research was trying to resolve the problems. Reasercher used trainning and Counseling method to resolve the problem. These methodincluding class study, discussion, case studyandfieldpractice. Implementing conflict mangament techniques was the goal of this reasearch. The result show that at the beginning of the tranning process the participants hardly know each other. Some even have interpersonnel conflict. After taking theoritical classes, Group discussions, case studies, the participants randomly divided into several groups. Conflict resolution techniques were simulated. At the end of the trainning, the participants were evaluated in group and individually. The result showed that the ability of reducing conflict potential was increased and all case given can be resolved in short time and can be accepted all participants. Concluded that the methodes were effective in reducing and resolute organizational potential conflicts.
\end{abstract}

Keywords: Conflict Management 


\section{PENDAHULUAN}

Wanita Katolik Republik Indonesia adalah sebuah organisasi kemasyarakatan yang beranggotakan para wanita yang berbasis Katolik. Wanita Katolik Republik Indonesia Cabang Roh Kudus dipimpin oleh Ibu J Wowor, SPd dan memiliki 2 ranting dibawahnya yaitu ranting Yohana dan Luisa. Kedua ranting ini memiliki anggota kurang lebih 40 orang. Jadi untuk cabang Roh Kudus secara total memiliki anggota 80 orang.Organisasi ini memiliki keunikan karena anggotanya semua adalah ibu rumah tangga. Organisasi Kemasyarakatan ini telah memiliki sejarah panjang dalam karyanya di seluruh Indonesia Dalam karyanya di lingkungan masyarakat WKRI menghadapi banyak peluang sekaligus tantangan. Semakin kompleksnya masalah kemasyarakatan membuat WKRI semakin memiliki ruang gerak dalam pelayanan. Namun pada saat yang sama mereka juga mendapatkan tantangan baik dari dalam maupun luar organisasi. Tantangan dari luar organisasi biasanya datang dari masyarakat sendiri yang sering tidak ingin dibantu atau tidak mampu menerima maksud baik dari perhimpunan ini. Sedangkan tantangan dari dalam adalah bagaimana menjadikan organisasi ini tetap stabil ditengah desakan inisiatif untuk maju dan semakin majunya pola pikir dari setiap anggota.

Sesuai observasi dan wawancara dengan beberapa ibu terungkap bahwa salah satu hal yang menyebabkan mereka enggan ikut dalam organisasi kemasyarakatan ini adalah seringnya terjadi konflik yang tidak terselesaikan diantara anggota organisasi. Jadi mereka memilih untuk tidak terlibat dalam organisasi ini dan memfokuskan pada pelayanan gereja saja. Dalam wawancara awal dengan ketua Presidium, diketahui bahwa konflik yang terjadi sering berawal dari hal hal sepele antar kader. Tapi kemudian meluas ke angggota lain tanpa bisa dikendalikan.

Konflik yang muncul dalamorganisasi yang merupakan akibat adanya perbedaan kepribadian, persepsi, tiap anggota organisasi yang saling berinteraksi sosial dalam pekerjaan. Tak dapat disangkal lagi apabila hingga kini kita makin akrab dengan konflik. Namun kini kita tak perlu lagi merasa takut dan ngeri mendengarnya. Karena, ternyata konflik yang terjadi tidak selamanya membawa akibat buruk sepanjang dapat dikelola dengan baik. Justru dengan adanya konflik akan memancing daya kreasi dan inovasi anggota organisasi baik secara individu maupun secara kolektif. Banyak cara atau pun trik yang dapat diterapkan untuk mengatasi dan bahkan mengurangi sensitivitas anggota terhadap pemicu konflik potensial di antara mereka. Berbagai macam training, seperti sensitivity training, diversity training programatau pun cross-cultural training (Noe, Hollenbeck, Gerhart, Wright, 2000)

Setiap kelompok dalam satu organisasi, dimana didalamnya terjadi interaksi antara satu dengan lainnya, memiliki kecenderungan timbulnya konflik. Konflik sangat erat kaitannya dengan perasaan manusia, termasuk perasaan diabaikan, disepelekan, tidak dihargai, ditinggalkan, dan juga perasaan jengkel karena kelebihan beban kerja. Perasaan-perasaan tersebut sewaktu-waktu dapat memicu timbulnya kemarahan. Keadaan tersebut akan mempengaruhi seseorang dalam melaksanakan kegiatannya secara langsung, dan dapat menurunkan produktivitas kerja organisasi secara tidak langsung dengan melakukan banyak kesalahan yang disengaja maupun tidak disengaja. Dalam suatu organisasi, kecenderungan terjadinya konflik, dapat disebabkan oleh suatu perubahan secara tibatiba, antara lain: kemajuan teknologi baru, persaingan ketat, perbedaan kebudayaan dan sistem nilai, serta berbagai macam kepribadian individu.

Masalah yang dihadapi oleh WKRI Cabang Roh Kudus adalah sebagai berikut :

1. Permasalahan yang sepele sering meluas dan tak terkendali

2. Penyelesaian konflik berlangsung lama karena penanganan yang tidak jelas

3. Kurangnya minat untuk bergabung dengan organisasi ini akibat konflik yang terjadi

Konflik sangat erat kaitannya dengan perasaan manusia, termasuk perasaan diabaikan, disepelekan, tidak dihargai, ditinggalkan, dan juga perasaan jengkel karena kelebihan beban kerja. Konflik yang muncul dalam organisasi yang merupakan akibat adanya perbedaan kepribadian, persepsi, tiap anggota organisasi yang saling berinteraksi sosial dalam pekerjaan. Tak dapat disangkal lagi apabila hingga kini kita makin akrab dengan konflik. Namun kini kita tak perlu lagi merasa takut dan ngeri mendengarnya. Karena, ternyata konflik yang terjadi tidak selamanya membawa akibat buruk 
sepanjang dapat dikelola dengan baik. Justru dengan adanya konflik akan memancing daya kreasi dan inovasi anggota organisasi baik secara individu maupun secara kolektif.

\section{a. Tujuan}

Kegiatan ini bertujuan untuk memberikan pembinaan dan pelatihan kepada anggota WKRI Cabang Roh Kudus bagaimana mengelola konflik dan tindakan preventif apa yang perlu dilakukan sebelum konflik itu terjadi.

\section{b. Sasaran}

Adapun sasaran dari kegiatan ini adalah pembinaan dan pelatihan kepada anggota WKRI Cabang Roh Kudus.

\section{c. Manfaat}

Pembinaan dan Pelatihan ini bermanfaat bagi para anggota WKRI CABANGROH KUDUS untuk memahami dan melatih manajemen konflik dan bagaimana mengambil tindakan prenventif sebelum konflik terjadi.

\section{d. Kerangka Pemecahan Masalah}

Masalah yang dihadapi oleh WKRI Cabang

Roh Kudus adalah sebagai berikut :

1. Permasalahanyang sepele sering meluas dan tak terkendali

2. Penyelesaian konflik berlangsung lama karena penanganan yang tidak jelas

3. Kurangnya minat untuk bergabung dengan organisasi ini akibat konflik yang terjadi

Untuk bisa mengantar para anggota pada kemampuan untuk menyelesaikan konflik yang baik diperlukan metode tertentu. kemampuan dasar antar anggota dan pengurus dalam menyelesaikan sebuah konflik tidak langsung dimiliki oleh setiap anggota WKRI tersebut. Untuk itu perlu ada penyeragaman persepsi untuk memahami dan melatih manajemen konflik dalam mengambil tindakan prenventif sebelum konflik itu terjadi. Dan Ketika semua anggota telah menyadari pentingnya tindakan prenvetif tersebut, maka sebaiknya perlu ada latihan dan penyuluhan serta pengembangan untuk melatih anggota memanajemen konflik konflik yang ada. Untuk itu diperlukan simulasi, praktek dan pengalaman langsung dari anggota.

Pada akhir penyuluhan dan pelatihan ini diharapkan anggota telah menguasai dan mampu memanage konflik dengan baik agar bisa menyelesaikan permasalahan dan tantangan serta kewajiban dalam suatu organisasi dalam hal ini WKRI dengan optimal.

\section{KAJIANLITERATUR \\ a. Definisi Konflik}

- Situasi yang terjadi ketika ada perbedaan pendapat atau perbedaan cara pandang diantara beberapa orang, kelompok atau organisasi.

- Sikap saling mempertahankan diri sekurang-kurangnya diantara dua kelompok, yang memiliki tujuan dan pandangan berbeda, dalam upaya mencapai satu tujuan sehingga mereka berada dalam posisi oposisi, bukan kerjasama.

\section{b. Aspek Positif dalam Konflik}

Konflik bisa jadi merupakan sumber energi dan kreativitas yang positif apabila dikelola dengan baik. Misalnya, konflik dapat menggerakan suatu perubahan :

- Membantu setiap orang untuk saling memahami tentang perbedaan pekerjaan dan tanggung jawab mereka.

- Memberikan saluran baru untuk komunikasi.

- Menumbuhkan semangat baru pada staf.

- Memberikan kesempatan untuk menyalurkan emosi.

- Menghasilkan distribusi sumber tenaga yang lebih merata dalam organisasi.

Apabila konflik mengarah pada kondisi destruktif, maka hal ini dapat berdampak pada penurunan efektivitas kerja dalam organisasi baik secara perorangan maupun kelompok, berupa penolakan, resistensi terhadap perubahan, apatis, acuh tak acuh, bahkan mungkin muncul luapan emosi destruktif, berupa demonstrasi.

\section{c. Penyebab Konflik}

Konflik dapat berkembang karena berbagai sebab sebagai berikut:

- Batasan pekerjaan yang tidak jelas

- Hambatan komunikasi

- Tekanan waktu

- Standar, peraturan dan kebijakan yang tidak masuk akal

- Pertikaian antar pribadi

- Perbedaan status

- Harapan yang tidak terwujud 


\section{d. Pengelolaan konflik}

Konflik dapat dicegah atau dikelola dengan:

- Disiplin: Mempertahankan disiplin dapat digunakan untuk mengelola dan mencegah konflik. Ketua presidium beserta para pengurus WKRI hendaknya harus mengetahui dan memahami peraturanperaturan yang ada dalam organisasi. Jika belum jelas, mereka harus mencari bantuan untuk memahaminya.

- Pertimbangan Pengalaman dalam Tahapan Kehidupan: Konflik dapat dikelola dengan mendukung Para anggota WKRI untuk mencapai tujuan sesuai dengan pengalaman dan tahapan hidupnya. Misalnya; Para anggota yang rajin dalam organisasi ini dapat dipromosikan untuk bisa mengikuti kegiatan kegiatan WKRI baik di dalam daerah atau diluar daerah dengan tujuan untuk memberikan tambahan wawasan dan pengetahuan yang baik tentang WKRI yang semestinya disamping mendapatkan teman baru atau sesama rekan WKRI lainnya di tempat/daerah yang lain untuk bisa saling berbagi informasi,berbagi ilmu tentang bagaimana mengembangkan WKRI, ataupun contoh yang lain adalah bagi anggota yang berprestasi dapat dipromosikan untuk menduduki jabatan yang lebih tinggi karena dianggap mampu untuk memajukan organisasi WKRI tersebut.

- Komunikasi: Suatu Komunikasi yang baik akan menciptakan lingkungan yang terapetik dan kondusif. Suatu upaya yang dapat dilakukan Ketua WKRI untuk menghindari konflik adalah dengan menerapkan komunikasi yang efektif dalam kegitan sehari-hari yang akhirnya dapat dijadikan sebagai satu cara hidup.

- Mendengarkan secara aktif: Mendengarkan secara aktif merupakan hal penting untuk mengelola konflik. Untuk memastikan bahwa para pimpinan serta pengurus WKRI telah memiliki pemahaman yang benar, mereka dapat merumuskan kembali permasalahan para anggota organisasi,ataupun menampung semua aspirasi,keluhan keluhan, ataupun kritikan kritikan anggota sebagai tanda bahwa mereka telah mendengarkan. b. Teknik atau kehlian mengelola Konflik

Pendekatan dalam resolusi konflik tergantung pada :

口 Konflik itu sendiri

口 Karakteristik orang-orang yang terlibat di dalamnya

口 Keahlian individu yang terlibat dalam penyelesaian konflik

a Pentingnya isu yang menimbulkan konflik

- Ketersediaan waktu dan tenaga

a. Strategi

口 Menghindar

Menghindari konflik dapat dilakukan jika isu atau masalah yang memicu konflik tidak terlalu penting atau jika potensi konfrontasinya tidak seimbang dengan akibat yang akan ditimbulkannya. Penghindaran merupakan strategi yang memungkinkan pihak-pihak yang berkonfrontasi untuk menenangkan diri. Pimpinan ataupun pengurus WKRI yang terlibat didalam konflik dapat menepiskan isu dengan mengatakan "Biarlah kedua pihak mengambil waktu untuk memikirkan hal ini dan menentukan tanggal untuk melakukan diskusi”

\section{- Mengakomodasi}

Memberi kesempatan pada orang lain untuk mengatur strategi pemecahan masalah, khususnya apabila isu tersebut penting bagi orang lain. Hal ini memungkinkan timbulnya kerjasama dengan memberi kesempatan pada mereka untuk membuat keputusan. Pimpinan ataupun pengurus yang menjadi bagian dalam konflik dapat mengakomodasikan pihak lain dengan menempatkan kebutuhan pihak lain di tempat yang pertama.

\section{Kompetisi}

Gunakan metode ini jika anda percaya bahwa anda memiliki lebih banyak informasi dan keahlian yang lebih dibanding yang lainnya atau ketika anda tidak ingin mengkompromikan nilai-nilai anda. Metode ini mungkin bisa memicu konflik tetapi bisa jadi merupakan metode yang penting untuk alasan-alasan keamanan.

\section{- Kompromi atau Negosiasi}

Masing-masing memberikan dan menawarkan sesuatu pada waktu yang bersamaan, saling memberi dan menerima, serta meminimalkan kekurangan semua pihak yang dapat menguntungkan semua pihak.

- Memecahkan Masalah atau Kolaborasi 
- Pemecahan sama-sama menang dimana individu yang terlibat mempunyai tujuan kerja yang sama.

- Perlu adanya satu komitmen dari semua pihak yang terlibat untuk saling mendukung dan saling memperhatikan satu sama lainnya.

\section{c. Pendekatan Situasi Konflik :}

- Diawali melalui penilaian diri sendiri

- Analisa isu-isu seputar konflik

- Tinjau kembali dan sesuaikan dengan hasil eksplorasi diri sendiri.

- Atur dan rencanakan pertemuan antara individu-individu yang terlibat konflik

- Memantau sudut pandang dari semua individu yang terlibat

- Mengembangkan dan menguraikan solusi

- Memilih solusi dan melakukan tindakan

- Merencanakan pelaksanaannya

\section{Pelaksanaan Kegiatan}

Kegiatan ini dilaksanakan sebagai wujud nyata kepedulian terhadap Wanita Katolik Republik Indonesia yang terus berkembang. Dalam perkembangannya sebagai suatu organisasi gereja Kaum ibu diharapkan akan semakin dewasa dalam bertindak dan semakin maju dalam berpikir serta memiliki bekal pengetahuan dan keterampilan dalam hidup.

Manajemen konfik tidak hanya diperlukan dalam organisasi kaum Ibu saja, tapi juga dalam kehidupan sehari hari baik di rumah sebagai orang tua, pengasuh pembimbing perkembangan anak, tapi juga sebagai ibu yang memiliki peran yang sangat penting dan luar biasa dalam kehidupan berkeluarga, bergereja dan bermasyarakat. Kegiatan Penyuluhan dan Pelatihan MAnajemen konflik ini dilaksanakan di Aula Karitas Paroki Roh Kudus Tomohon. Seluruh Anggota yang berjumlah 80 orang diundang dalam kegiatan ini, namun yang mengikuti kegiatan ini hanya 30 orang anggota, karena yang lain sibuk dengan tugas dan kegiatan ditempat pekerjaan masing masing. Peserta yang hadir berasal dari anggota cabang baik Ranting Sta. Louisa Dan Ranting Sta. Yohana yang ada di Paroki Roh Kudus di kota Tomohon. Kegiatan ini dilaksanakan pada tanggal 02 - 03 Oktober 2015.

\section{METODE DAN TEKNIK YANG DIGUNAKAN}

1. Materi

Rencana materi yang akan diberikan mencakup:

a. Mengenali Penyebab Konflik

b. Teknik Atau Keahlian Untuk Mengelola Konflik

c. Tindakan preventif sebelum konflik terjadi

d. Simulasi dan games yang membangun kemampuan mengelola Konflik

2. Metode

Metode yang digunakan dalam kegiatan pengabdian ini adalah metode ceramah, tanya jawab, studi kasus, dan praktek lapangan.

3. Teknik

Teknik yang digunakan dalam kegiatan ini adalah secara individual dan kelompok.

\section{EVALUASI}

Keberhasilan kegiatan ini bukan semata mata diukur dari jumlah peserta yang ikut tapi dari output yang dihasilkan setelah kegiatan ini dilaksanakan. Selama kegiatan ini dilangsungkan telah banyak perkembangan yang terjadi sesuain dengan pengamatan. Kemampuan bersosialisasi, berkomunikasi serta bekerja sama semakin meningkat.

Sebagai contoh sederhana, pada awal kegiatan ini, setelah menerima pemaparan materi, para anggota ada yang belum saling kenal, ada juga yang saling kenal tapi bermusuhan. Dan dalam kegiatan pelatihan ini, Mereka kemudian dikelompokkan secara acak dan diberikan contoh kasus kemudian mereka membuat simulasi manajemen konflik. Pada awalnya memang hasilnya tidak maksimal. Hal ini disebabkan karena mereka belum bisa mengaplikasikan teori yang sudah diberikan. Setelah beberapa simulasi, mereka akhirnya mampu menangkap maksudnya dan mulai berusaha memecahkan masalah lewat kasus yang diberikan, serta mulai saling mendengarkan. Di akhir kegiatan ini mereka diminta untuk merefleksikan keadaan organisasi mereka selama ini, terutama kegiatan kegiatan dan program yang tidak berjalan dengan sempurna. Satu persatu mereka kemudian mulai bisa muncul dengan solusi solusi sederhana yang selama ini tidak mereka pikirkan. Diakhir kegiatan ini, ditarik kesimpulan bahwa para peserta bisa memahami bagaimana cara meminimalisasi konflik dalam satu organisasi, dan melatih cara memanajemen 
konflik yang ada serta berusaha mengambil tindakan prenventif sebelum konflik terjadi.

\section{KESIMPULAN}

Berdasarkan fakta diatas penulis memandang perlu adanya penyuluhan dan pelatihan mengenai manajemen konflik di dalam Organisasi Kemasyarakatan WKRI ini. Sebagai perwujudan Tri Dharma Perguruan tinggi terutama dalam aspek pengabdian kepada masyarakat pembinaan kaum Ibu dalam perhimpunan ini dipandang penting oleh penulis dalam upaya membekali mereka dalam karya mereka di lingkungan Keluarga,masyarakat dan gereja. Fokus dalam penyuluhan dan pelatihan ini adalah bagaimana mengelola konflik yang terjadi di dalam organisasi.

\section{REFERENSI}

Ann Marriner -Tomey ( 1996 ). Guide To Nursing Management and Leadership. Mosby - Year Book, Inc St Louis USA.

Arifin, Rois, dkk. 2003. Perilaku Organisasi, Edisi Pertama, Cetakan Pertama, Bayumedia, Malang.

Arfani, Noer Riza. 2005. Governance dan Pengelolaan Konflik, Makalah disampaikan pada "Worshop Analisis Kebijakan Publik, Magister Studi Kebijakan UGM, Yogyakarta.

Dahrendorf, Ralf. 1986. Konflik dan Konflik Dalam Masyarakat Industri : Sebuah Analisa-Kritik, Cetakan Pertama, Alih Bahasa Ali Mandan, Rajawali Pers, Jakarta.

Strukturalisme Konflik

II : Suatu Usul Bagi Penjelasan Struktu Sosial, dalam Poloma, M Margaret. 1987. Sosiologi Kontemporer, Cetakan kedua, Alih Bahasa Tim Yasogama, Rajawali, Jakarta.

Fisher, Simon, dkk. 2001. Mengelola Konflik: Keterampilan dan Strategi Untuk Bertindak, Cetakan Pertama, Alih Bahasa S.N. Kartikasari, dkk, The British Counsil, Indonesia, Jakarta.

Hendricks, William. 2004. Bagaimana Mengelola Konflik : Petunjuk Praktis Untuk Manajemen Konflik yang Efektif, Alih Bahasa Arif Susanto, Cetakan Kelima, Bumi Aksara, Jakarta.
Pruitt G. Dean dan Jeffrey Z. Rubbin. 2004. Teori Konflik Sosial, Seri Psikologi Sosial, Cetakan Kelima, Alih Bahasa Helly P. Soetjipto dan Sri Mulyantini, Pustaka Pelajar, Jakarta. 